\title{
Vision-Based Leaders And Their Followers In Retail Stores: Relationships And Consequences In Australia
}

Sooksan Kantabutra, Mahidol University, Bangkok, Thailand

Pisanu Vimolratana, Mahidol University, Bangkok, Thailand

\begin{abstract}
Leaders are exhorted to espouse vision, but little is known about how vision is used by leaders in Australian retail stores. The present study tested relationships between store manager passion for vision, motivation of staff and use of vision among staff, and leadership outcomes of staff and customer satisfaction in Australian apparel retail stores. Stores with vision are associated with higher staff satisfaction and more frequent use of vision among staff. Store manager passion directly predicts improvements in motivation of staff, use of vision among staff and staff satisfaction. Motivation of staff directly predicts enhanced staff satisfaction, while use of vision among staff directly predicts improved staff and customer satisfaction.
\end{abstract}

Keywords: leadership, emotions, motivation, followership, vision, passion

\section{INTRODUCTION}

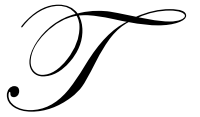

he Australian retail industry is an industry of change with a dynamic and constantly evolving environment. Since 1998, strong consumer spending had produced booming sales and profits for retailers (Australian Centre for Retail Studies, 2006). However, a slowing market, an interest rate rise, and higher petrol prices brought about difficult trading conditions in 2005 (Australian Centre for Retail Studies, 2006). The retail slowdown in 2005 has placed on a number of businesses with many companies being acquired by larger retailers. There are also a number of challenges facing Australian retailers, including new retail formats, heavy discounting by major retailers, declines in the property market, high petrol prices, rising retail rents, and shortages of retail staff (Australian Centre for Retail Studies, 2006). Following the collapse of financial markets and rapid deterioration of the global economy through late 2008, 2009 has been the most difficult year in decades for Australian retail businesses (ANZ Industry Outlook, 2009). In such a challenging and constantly changing retail context, what kind of leadership is needed for Australian retail organizations, particularly smaller ones, to survive and remain competitive? To many writers, leadership with vision as a core component is the answer, with promulgating a vision frequently being seen as one of the essential tasks that top organizational leaders perform (Kantabutra, 2010). In response to the increasing pace of change, vision-based leaders prepare for future actions by creating a sense of urgency towards change, formulating and communicating vision to their followers (Kotter, 1996).

This paper presents the results of a study examining hypothesized relationships between store manager passion, motivation of staff, use of vision as a guide among staff, and leadership outcomes of staff and customer satisfaction. Predictions were tested in Australian apparel stores, and the outcomes are presented and discussed below. Managerial implications and future research directions are also discussed.

\section{VISION}

Clearly, the importance of vision has been emphasized by leadership scholars in both theoretical discussions and research (Kantabutra, 2010). There is no doubt that many leadership scholars have seen vision as 
important to leadership, strategy implementation, and change (e.g. Collins \& Porras, 1994; Humphreys, 2004; Kantabutra \& Avery, 2010; Kotter, 1990; Sashkin, 1988). Although some managers dismiss visions as irrelevant to organization performance (see Rynes, Colbert \& Brown, 2002), businesses need a purpose (Avery, 2005). Supporting this view, Handy (2002) argues that the purpose of a business goes beyond making a profit, to something "better", a higher-level purpose. In particular, researchers (e.g. Hamel \& Prahalad, 1989) have asserted that an organization with a well-articulated vision can achieve sustained competitive advantage over those organizations lacking such a vision.

Research into vision is however complicated by a lack of commonly agreed definitions (Kantabutra \& Avery, 2010). Moreover, practitioners may also be confused as to which definition to adopt, as they are equally confused with the titles of mission, vision, values, beliefs, principles and strategic intent/ direction (Baetz \& Bart, 1996; Kantabutra \& Avery, 2010). To avoid this definitional issue, Mumford and Strange (2005) suggest that vision is ultimately a mental model used both to understand system operations and guide actions within the system. Baum, Locke and Kirkpatrick (1998) defined "vision" as each leader defines it, arguing that it is the leader's actual vision that guides his/her behavior. Thus, we defined vision in the present study as a mental model each store manager defined it for his/her store.

\section{LEADER AND FOLLOWER VARIABLES}

Jick (2001) suggests that vision contributes only $10 \%$, and implementation is responsible for the rest. The following leader and follower variables are proposed as necessary for realizing a vision: Leader passion, motivation of staff and vision guiding. We hypothesize that leaders must be passionate about their visions first to, among other things, motivate their followers to achieve visionary goals. Emotionally committed followers then use their leader vision to guide daily decision making and operations to achieve superior performance outcomes. Each variable is discussed accordingly below.

\section{Leader Passion}

Leader passion for vision is said to affect followers' outcomes and overall business performance (e.g. Kantabutra \& Vimolratana, 2009; Kotter, 1996). Visionary leaders live their vision by making all their actions and behaviors consistent with it, and by creating a sense of urgency and passion for its attainment (Kantabutra, 2009; Nanus, 1992). They often express passion for their agendas in the hope of exciting others to support their vision (Nanus, 1992). They galvanize people to action by infusing leadership with their own passion for work, thus tapping followers' emotions as well as their minds (Daft, 2005). Visionary leaders inspire a shared vision by their passionate belief that they can make a difference (Kouzes \& Posner, 1995). Through their strong appeal and quiet persuasion, they enlist followers in the dream, breathe life into the shared vision, and get people to see the exciting future possibilities.

Moreover, outstanding leaders behave consistently with their vision (Bennis, 1984; Conger \& Kanungo, 1988; Kantabutra, 2009). They actually embrace the ideas they communicate about their vision. When leaders truly believe in an idea, they want to share it with others, and their actions will match their words (Daft, 1999). Consistent behavior also reflects leadership's integrity (e.g. Kantabutra, 2009; Kantabutra \& Vimolratana, 2009; Kouzes \& Posner, 1987; Locke et al., 1991). This integrity is important because followers are able to recognize shortly to what extent their leader really stands behind the vision, not only within his/her mind, but also with his/her heart (Kantabutra, 2009; Parikh \& Neubauer, 1993). Effective leaders sometimes earn followers' trust by being willing to incur great personal risk (Daft, 2005). Putting themselves on the line affirms them as passionate advocate for the vision.

Leader passion was defined in the present study as the extent to which a store manager was perceived by staff (a) to be passionate about his/her vision, (b) to be supportive to his/her vision by actions, and (c) to act consistently with his/her vision. 


\section{Motivation of Followers}

Vision as a leadership tool can energize followers and garner their commitment (Daft, 2005; Kantabutra, 2009). A powerful vision frees followers from the mundane by providing them with a challenge worthy of their best efforts. Many followers commit their time and energy voluntarily to causes they believe in. Vision indeed needs to transcend the bottom line because people are willing, and even eager, to commit to something truly worthwhile (Nanus, 1992). A powerful vision can therefore motivate followers (Kantabutra \& Avery, 2010).

In terms of leader roles, numerous writers suggest that visionary leaders motivate followers to achieve superior performance (e.g. Awamleh \& Gardner, 1999; Bass, 1985; Bass \& Riggio, 2010). Many (e.g. Chia, 1998; Goleman, 1998; Kantabutra, 2008; 2009) have even associated motivation with performance outcomes, because leaders cannot deliver performance outcomes on their own. They must motivate others to work towards them. While trying to achieve a challenging vision, followers can become exhausted, frustrated, and disenchanted, and thus leaders must encourage their followers to carry on. House and Shamir (1993) claimed that visionary leaders impact follower attitudes, satisfaction, and performance. Visionary leaders motivate followers by instilling faith in a better future, particularly with goals that are distant, non-specific, and desired, and by creating internalized personal or moral commitment to the vision, mission, or goal. This predisposes an individual to want to continue the relationship, role, or course of action within his/her organization. Effective leaders motivate their followers through devices such as the use of formal authority, role modelling, building self-confidence, creating challenge through goal-setting, delegating, and rewarding and punishing (Kantabutra, 2008, 2009; Locke et al., 1991). It is clear that motivation is related in some sophisticated ways to performance outcomes.

Motivation in this study was defined as the extent to which a store manager was perceived by staff (a) to act as a role model for staff, (b) to build staff's self confidence, (c) to reward staff who acted consistently with the vision, (d) to provide resources and support services to staff, and (e) to encourage staff to make more decisions regarding daily operations.

\section{Vision Guiding}

Follower roles in the Visionary leadership process are under studied, although they are critical to organizational performance and ability to sustain business success (e.g. Avery, 2004; Daft, 2005; Kantabutra, 2009). Both leader and follower roles need to be proactive (Daft, 2005; Kantabutra, 2009). Together they can achieve a shared vision. An effective follower is both a critical, independent thinker and active in the organization (Daft, 2005; Kantabutra \& Vimolratana, 2009). Characterized by mindfulness and a willingness to act, effective followers are capable of self-management (Daft, 2005). They are willing to accept responsibility, serve the needs of the organization, challenge authority, participate in change, and leave the organization when necessary (Chaleff, 1995). In the visionary leadership context, one function of a vision is therefore to facilitate decision making, initiative, and discretion by followers at all levels (Kantabutra, 2009; Yukl, 1998). As a navigator, vision is regarded as possessing potent orienting capacities for followers (Davis \& Meyer, 1998; Kantabutra, 2009). Consistent with this view, Kantabutra's vision theory (2009) asserts that an effective vision be inclusive to all organizational interests, thereby allowing followers to interpret the vision in their own innovative ways to guide their duties. Whether and how followers use the vision to guide their work could impact individual and collective performance outcomes. In such a context, followers' emotional commitment to their leader's vision is considered important for a vision to take effect, because when followers are committed, they tend to be willing to work towards the vision (Collins \& Porras, 1994; Kantabutra \& Avery, 2010; Lipton, 1996). Organizations that create a meaningful vision for the future are often able to stimulate emotions in their people (Ghoshal \& Bruch, 2002; Kantabutra \& Avery, 2010). Panda and Gupta (2003) concluded that a transformational leader may be able to elicit emotional commitment from his/her subordinates by providing inspiration, intellectual stimulation, and individualized consideration to them. Eventually, vision inspires people by transcending the bottom line (Kantabutra, 2009; Nanus, 1992).

Vision guiding was defined in the present study as the extent to which a staff member (a) used his/her store manager's vision to guide daily activities, and (b) felt emotionally committed to his/her store manager's vision. 


\section{Leadership Outcomes}

Customer and employee satisfaction were adopted in this study as two leadership outcomes (Bass, 1985; Kantabutra \& Vimolratana, 2009; Oliver, 1998), although we do not suggest that they exhaustively explain overall organizational performance because (a) a close link between employee satisfaction and performance has not been established in previous studies (e.g. Iaffaldano \& Muchinsky, 1985; Locke, 1976; Vroom, 1964); and (b) limits to customer satisfaction as a performance indicator exist (e.g. Heskett, Jones, Loveman, Sasser, \& Schlesinger, 1994; Passikoff, 1997). However, both satisfaction are more responsive to leaders' behaviour within the short time frame of the study than financial performance measures, and could be obtained from small businesses, therefore suitable for the purpose of the present study.

Employee satisfaction is the extent to which a staff member was satisfied with his/her job as measured by pay, fringe benefits, autonomy, task requirements, staff policies, interaction, professional status, guidance, coworkers, recognition, and career advancement (Slavitt, Stamps, Piedmont \& Hasse, 1986). Customer satisfaction is the extent to which a customer was satisfied with overall store services as measured by staff availability, friendliness, decoration, presentation of goods, cleanliness, quality of goods, richness of choice, waiting time for checkout, payment methods, price labelling, special offers and sales, shopping hours, prices, and shelffrack layout (Hackl, Scharitzer \& Zuba, 2000).

\section{HYPOTHESES}

Based on the literature review, Figure 1 below depicts a structural model tested in the present study. Store manager passion can be postulated to have direct positive effects on motivation of staff, which in turn creates direct positive effects on vision guiding. Vision guiding then can be postulated to have direct positive effects on staff satisfaction, which in turn creates direct positive effects on customer satisfaction. Directed effects paths are shown by the bold lines in Figure 1. Store manager passion can also be postulated to have indirect positive effects on vision guiding, staff and customer satisfaction. Similarly, motivation of staff can be postulated to have indirect positive effects on staff and customer satisfaction, while vision guiding can be postulated to have indirect positive effects on customer satisfaction. Indirect effects paths are shown by the dot lines in Figure 1.

Figure 1: Structural Model Showing Relationships between Store Manager Passion, Motivation of Staff, Vision Guiding, and Staff and Customer Satisfaction

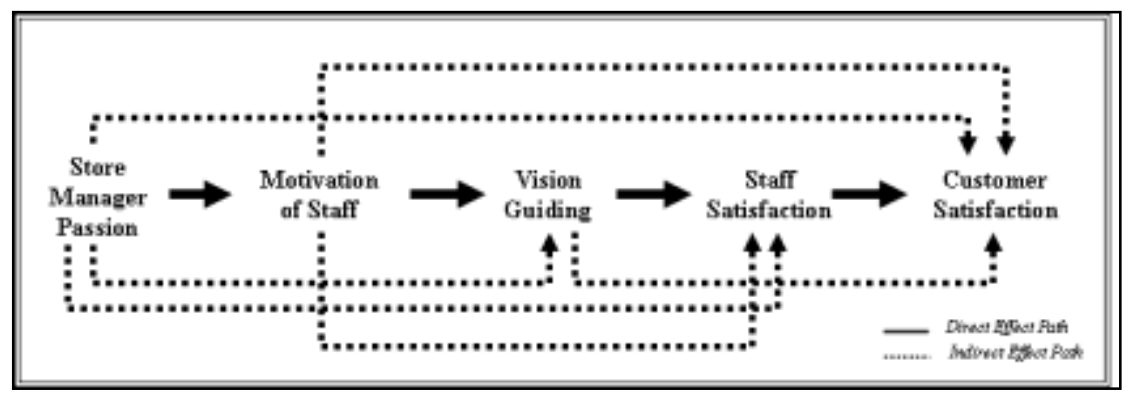

Accordingly, the following directional hypotheses were generated:

Hypothesis 1: Store manager passion is directly predictive of enhanced motivation of staff

Hypothesis 2: $\quad$ Store manager passion is indirectly predictive of enhanced vision guiding

Hypothesis 3: Motivation of staff is directly predictive of enhanced vision guiding

Hypothesis 4: Store manager passion is indirectly predictive of enhanced staff satisfaction

Hypothesis 5: Motivation of staff is indirectly predictive of enhanced staff satisfaction

Hypothesis 6: Vision guiding is directly predictive of enhanced staff satisfaction

Hypothesis 7: Store manager passion is indirectly predictive of enhanced customer satisfaction 
Hypothesis 8: Motivation of staff is indirectly predictive of enhanced customer satisfaction

Hypothesis 9: Vision guiding is indirectly predictive of enhanced customer satisfaction

Hypothesis 10: Staff satisfaction is directly predictive of enhanced customer satisfaction

\section{METHODOLOGY}

The sample was drawn from apparel stores in Sydney, Australia, that sell brand-new, finished clothing products for individual use, excluding shoes and accessories. Both independent stores and those belonging to a parent company were sampled. All were located in a shopping mall and had their own identity of being in a clearlydefined walled area. Nineteen shopping centers in Sydney major shopping areas, including Blacktown, Bondi Junction, Burwood, Chatswood, Circular Quay, Darling Harbour, Eastwood, George Street, Hay Market, Hornsby, North Ryde, Parramatta, Pitt Street, and The Rocks, were selected. The major shopping areas were systematically chosen, because they geographically represented the population of the entire Sydney's major shopping areas. In choosing, two shopping malls directories were consulted. Small shopping malls considered "too small" with one staff member were eliminated. All qualifying stores in each centre approached. Of these, 111 stores (70\%) agreed to participate, with 48 stores (30\%) declining. From the participating stores, store managers, and up to three staff and three customers were asked to respond to their relevant questionnaires. Store managers, staff and customer samples are convenient as they comprise of those who were willing to participate in the study. Three staff members per store represented over $50 \%$ of each store's staff population on average, given that $70 \%$ of the Australian Retailer Association's members in New South Wales, employed five or fewer employees on average (http://www.ara.com.au/). Since the customer population was unknown, a minimum of three customers per store was adopted as the customer sample size, consistent with the staff sampling.

Store managers refer to those full-time store employees who manage their own stores and are stationed there daily. The latter criterion was important because the study was interested in the effects of one manager's vision only. Staff members include fulltime, part time and casual employees working under the store managers, and customers are individuals who were observed buying a product or service during the researcher's visit. If no customer was observed buying during the researcher's visit, the researcher revisited the store until three customers agreed to participate or three visits were made to the store. Finally, the total of 148 staff members and 214 customers were surveyed.

\section{DATA COLLECTION AND ANALYSIS}

Separated sets of questionnaire were used for store managers, staff and customers. A nine-point ordinal scale underlay all questionnaire items measuring the five domains in Figure 1. Three research assistants, trained in administering the questionnaires, interviewed store managers and their staff and customers. The research assistant asked the store manager if he/she would agree to participate in the study, and allow the research assistant to approach his/her staff and customers. If the store manager agreed to participate, the research assistant proceeded to instruct him/her in how to answer the questionnaire. After the store manager finished answering the questionnaire, the research assistant would ask for permission to approach his/her staff and customers. The staff member was first informed that no one would be able to learn about his/her responses. The staff member was then asked if he/she was willing to participate in the study. If he/she agreed, the research assistant would accompany him/her out of the store to fill in the questionnaire. Although the store manager could see which staff completed the questionnaire, he/she was not able to access the staff's responses. After the first staff member agreed to participate, the research assistant then continued by approaching the next staff member he/she met at the store until three staff questionnaires were completed, or until it was not possible to complete three staff questionnaires (i.e. a store had only two staff members). Similarly, the customer was asked if he/she was willing to participate in the study. If he/she was willing to do so, the research assistant instructed him/her to answer the questionnaire. The research assistant continued by approaching the next buying customer until three customer questionnaires were completed, or until it was not possible to complete three customer questionnaires (i.e. a store did not have three customers who were buying a product during the day of visit at the time the research assistant was in the store). Response rates for staff and customers were $44 \%$ and $64 \%$, respectively. Those who refused were not re-approached. 
The store manager questionnaire collected data on vision and demographic information. Store managers indicated whether they had a vision for their store (yes/no). Questions measuring store manager passion, motivation of staff and vision guiding were included in the staff questionnaire. Staff also responded to six components of job satisfaction based on criteria developed by Slavitt et al. (1986). The customer questionnaire collected data on 14 items measuring customer satisfaction on services at the store using criteria from Hackl, Scharitzer and Zuba (2000).

Combining scores of sub-variables to form the five domain constructs were considered justified, according to results of confirmatory factor analyses (see Tables 1 and 2), although some relevant customer and staff satisfaction items were dropped because of their extraction values not exceeding or close to 0.7 (Hair, Black, Babin, Anderson \& Tatham, 2006). Cronbach's alphas were employed to confirm the reliability of store manager passion, motivation of staff, vision guiding, and customer and staff satisfaction variables (see Tables 1 and 2). These variables indicated Cronbach's alpha values exceeding or close to 0.7 , an acceptable reliability value (Nunnally, 1978).

Table 1: Construct Validity and Reliability for Store Manager Passion, Motivation of Staff and Vision Guiding

\begin{tabular}{|c|c|c|c|c|c|c|c|c|}
\hline \multirow{2}{*}{ Na. } & \multirow{2}{*}{ Variable Name } & \multirow{2}{*}{ Measured Item } & \multirow{2}{*}{$\mathrm{N}$} & \multicolumn{4}{|c|}{ Rotated Component Matrix } & \multirow{2}{*}{$\begin{array}{c}\text { Crunbach's } \\
\text { Alnba }\end{array}$} \\
\hline & & & & 1 & 2 & 3 & Cotmmuanaities & \\
\hline \multirow{3}{*}{1} & \multirow{3}{*}{$\begin{array}{c}\text { Store } \\
\text { Managet } \\
\text { Passion }\end{array}$} & Store Manager Passion for Viston & 84 & 0.84 & & & 0.78 & \multirow{3}{*}{0.91} \\
\hline & & Store Manager Support for Vision & 84 & 0.92 & & & 0.87 & \\
\hline & & Store Manager Behavioral Consistency whth Vision & 84 & 0.92 & & & 0.92 & \\
\hline \multirow{5}{*}{2} & \multirow{5}{*}{$\begin{array}{c}\text { Motrvation of } \\
\text { Staff }\end{array}$} & Store Manager Acting as Role Model for Staff & 84 & & 0.80 & & 0.66 & \multirow{5}{*}{0.85} \\
\hline & & Staff Self-Confidence Buidang & 84 & & 0.73 & & 0.60 & \\
\hline & & Reward to Staff Acting Consistently with Vieion & is 4 & & 0.75 & & 0.62 & \\
\hline & & Provision of Resources and Sugport Services for Staff & 84 & & 0.89 & & 0.82 & \\
\hline & & Encouragement of Staff to Make Daily Operation Decisions & 84 & & 0.74 & & 0.62 & \\
\hline \multirow{3}{*}{3} & \multirow{2}{*}{ Vision Griding } & Staff Use of Store Manager Vision to Gude Dacky Activities & 84 & & & 0.86 & B.75 & \multirow{2}{*}{0.73} \\
\hline & & Staff Emotional Corraritment to Store Manager Viston & 84 & & & 0.88 & 0.81 & \\
\hline & & & \multicolumn{5}{|c|}{ *V arimar with Kaiser Hormalization } & \\
\hline
\end{tabular}

Table 2: Construct Validity and Reliability for Staff and Customer Satisfaction

\begin{tabular}{|c|c|c|c|c|c|c|c|}
\hline \multirow{2}{*}{ No. } & \multirow{2}{*}{$\begin{array}{c}\text { Variable } \\
\text { Name }\end{array}$} & \multirow{2}{*}{ Measured Item } & \multirow{2}{*}{$\mathrm{N}$} & \multicolumn{3}{|c|}{ Rotated Component Matrix } & \multirow{2}{*}{$\begin{array}{c}\text { Cronbach's } \\
\text { Alpha }\end{array}$} \\
\hline & & & & 1 & 2 & Communalities & \\
\hline \multirow{5}{*}{1} & \multirow{5}{*}{$\begin{array}{c}\text { Staff } \\
\text { Satisfaction }\end{array}$} & Autonomy & 84 & & 0.84 & 0.72 & \multirow{5}{*}{0.89} \\
\hline & & Task Requirements & 84 & & 0.85 & 0.75 & \\
\hline & & Staff Policies & 84 & & 0.86 & 0.74 & \\
\hline & & Interaction & 84 & & 0.80 & 0.73 & \\
\hline & & Guidance & 84 & & 0.72 & 0.66 & \\
\hline \multirow{12}{*}{2} & \multirow{11}{*}{$\begin{array}{l}\text { Customer } \\
\text { Satisfaction }\end{array}$} & Staff Availability & 84 & 0.83 & & 0.72 & \multirow{11}{*}{0.96} \\
\hline & & Friendliness & 84 & 0.86 & & 0.76 & \\
\hline & & Decoration & 84 & 0.86 & & 0.76 & \\
\hline & & Presentation of Goods & 84 & 0.87 & & 0.80 & \\
\hline & & Cleanliness & 84 & 0.82 & & 0.71 & \\
\hline & & Quality of Goods & 84 & 0.87 & & 0.77 & \\
\hline & & Richness of Choice & 84 & 0.81 & & 0.68 & \\
\hline & & Waiting Time for Checkout & 84 & 0.71 & & 0.58 & \\
\hline & & Payment Methods & 84 & 0.73 & & 0.60 & \\
\hline & & Price Labeling & 84 & 0.83 & & 0.74 & \\
\hline & & Shelf/Rack Layout & 84 & 0.82 & & 0.71 & \\
\hline & & & & \multicolumn{3}{|c|}{ *Varimax with Kaiger Normalization } & \\
\hline
\end{tabular}

Since the literature consistently indicates that visionary leadership positively impacts leadership outcomes, one tailed tests were adopted at the 5\% level of significance for testing Hypotheses $1-10$.

\section{RESULTS}

Store managers had been with the stores for 3.39 years on average. Staff members consist of full-time (30\% of respondents), part-time (23\%), and casual (47\%), respectively, and had worked in their stores for an average of 2.64 years. Stores average 6.29 staff members in total, including 2.34 full-time, 2.47 part-time, and 4.35 causal staff 
members. Among the 111 stores, 84 (75.68\%) store managers reported having a vision for their store. The chisquare test indicates that stores with a vision are significantly associated with higher staff satisfaction and more frequent use of vision as a guide among staff (see Table 3). Averaged total scores and pooled standard deviations for the major variables are presented in Table 4.

The correlation analysis indicates that (1) store manager passion is significantly correlated to motivation of staff, (2) vision guiding is significantly correlated to staff satisfaction, and (3) staff and customer satisfaction are significantly correlated. Therefore, these variables are justified for inclusion in subsequent regression analyses. Although motivation of staff is not significantly correlated to vision guiding, it is still justified for inclusion in subsequent regression analyses because motivation of staff is significantly correlated to both store manager passion and staff satisfaction.

Table 3: Chi-square Test for Dependence

\begin{tabular}{|c|c|c|l|c|}
\hline \multirow{2}{*}{ No. } & Variable Name & \multirow{2}{*}{$*$} & \multicolumn{2}{|c|}{$\begin{array}{r}\text { Nependence to Store } \\
\text { having Vision }\end{array}$} \\
\cline { 3 - 5 } & & & Chi-Square & d.f. \\
\hline 1 & Store Manager Passion & 111 & 18.08 & 18 \\
\hline 2 & Motivation to Staff & 111 & 14.28 & 28 \\
\hline 3 & Vision Guiding & 111 & $35.10^{* * *}$ & 16 \\
\hline 4 & Staff Satisfaction & 111 & $59.47 * * *$ & 34 \\
\hline 5 & Customer Satisfaction & 111 & 74.98 & 73 \\
\hline$*_{p}<0.10, * *_{p}<0.05, * * * p<0.01$ & & & \\
\hline
\end{tabular}

Table 4: Means, Pooled Standard Deviations, and Correlation Analyses

\begin{tabular}{|c|c|c|c|c|c|c|c|c|c|}
\hline No. & Variable Name & $\mathrm{N}$ & Mean & s.d. & 1 & 2 & 3 & 4 & 5 \\
\hline 1 & Store Manager Passion & 84 & 8.13 & 1.21 & 1 & & & & \\
\hline 2 & Motivation to Staff & 84 & 7.72 & 1.33 & $0.42^{* * * *}$ & 1 & & & \\
\hline 3 & \begin{tabular}{|l|} 
Vision Guiding \\
\end{tabular} & 84 & 7.53 & 1.55 & $0.33^{* * * *}$ & $0.19 * *$ & 1 & & \\
\hline 4 & Staff Satisfaction & 84 & 7.20 & 1.52 & $0.51 * * *$ & $0.48^{* * *}$ & $0.39 * * *$ & 1 & \\
\hline 5 & Customer Satisfaction & 84 & 6.88 & 1.14 & $0.15^{*}$ & 0.03 & $0.31 * * *$ & $0.16^{*}$ & 1 \\
\hline \multicolumn{2}{|c|}{$*_{p}<0.10, * * p<0.05, * * *_{p}<0.01$} & & & & & & & & \\
\hline
\end{tabular}

In testing Hypotheses 1-10, Structural Equation Modelling (SEM) was considered, but the sample size of the present study does not meet the minimum sample size of 150 as required by SEM (Hair et al., 2006). Therefore, multiple regression analysis was instead adopted. It must be noted that significant direct effect or relationship is defined in the present study as an effect from an observed independent variable that showed "significant" at $p<0.05$ when all other observed independent variables were simultaneously tested in a regression analysis.

As expected, store manager passion is directly predictive of motivation of staff (see Table 5). Therefore, Hypothesis 1 is accepted. Store manager passion is also directly predictive for enhanced Vision Guiding, while motivation of staff is indirectly predictive of vision guiding $(\beta=0.23$, s.e. $=0.13, p=0.039)$. Therefore, Hypotheses 2 and 3 are not accepted.

Store manager passion, motivation of staff and vision guiding are all directly predictive of enhanced staff satisfaction. Thus, Hypotheses 4 and 5 are not accepted while Hypothesis 6 is accepted. Vision guiding is the only direct predictor of enhanced customer satisfaction, although staff satisfaction still has an indirect, positive effect on customer satisfaction $(\beta=0.35$, s.e. $=0.06, p=0.00)$. The other variables of store manager passion and motivation of staff do not have any effect on customer satisfaction, neither directly nor indirectly. Therefore, Hypotheses 7 to 10 are not accepted. In conclusion, only Hypotheses 1 and 6 are accepted, while the rest are not. 
Table 5: Regression Table

\begin{tabular}{|c|c|c|c|c|c|}
\hline \multirow{2}{*}{ Dependent Variables } & \multirow{2}{*}{$\mathrm{N}$} & Motivation of Staff & Vision Guiding & Staff Satisfaction & Customer Satisfaction \\
\hline & & $\mathrm{H} 1$ & $\mathrm{H} 2-\mathrm{H} 3$ & $\mathrm{H} 4-\mathrm{H} 6$ & $\mathrm{H} 7-\mathrm{H} 10$ \\
\hline \multirow{2}{*}{ Store Manager Passion } & \multirow{2}{*}{84} & $0.46^{* * *}$ & $0.38^{* * *}$ & $0.28 * * *$ & 0.04 \\
\hline & & -0.11 & -0.15 & $(0.09)$ & -0.09 \\
\hline \multirow{2}{*}{ Motivation of Staff } & \multirow{2}{*}{84} & & 0.08 & $0.26^{* * * *}$ & -0.05 \\
\hline & & & -0.14 & -0.08 & -0.08 \\
\hline \multirow{2}{*}{ Vision Guiding } & \multirow{2}{*}{84} & & & $0.17^{* * *}$ & $0.16^{* * *}$ \\
\hline & & & & -0.07 & -0.07 \\
\hline \multirow{2}{*}{ Staff Satisfaction } & \multirow{2}{*}{84} & & & & 0.04 \\
\hline & & & & & -0.11 \\
\hline \multicolumn{2}{|l|}{ Adjusted $\mathrm{R}^{2}$} & 0.17 & 0.09 & 0.37 & 0.06 \\
\hline \multicolumn{2}{|l|}{$\mathrm{F}$} & $17.56^{* * *}$ & $5.03 * *$ & $17.36^{* * *}$ & $2.32 *$ \\
\hline \multicolumn{3}{|c|}{ Unstandardized coefficients; Standard errors in parentheses } & & & \\
\hline \multicolumn{2}{|c|}{$*_{p}<0.10, * *_{p}<0.05, * * *_{p}<0.01$} & & & & \\
\hline
\end{tabular}

\section{DISCUSSION}

The store managers' longer period of time with stores indicates a high likelihood that staff members were influenced by the leadership style of their store managers. Since stores in the present study are quite small and with the store managers' longer period of time with stores, staff members were more likely able to closely observe their store managers' leadership style. Both observations indeed strengthen findings in the present study.

Store managers with vision are associated with higher staff satisfaction and more frequent use of vision as a guide among staff that directly predicts improvement in customer satisfaction in Australian retail stores. It also comes as no surprise that staff in stores with vision more frequently use the vision to guide their daily operations than stores without vision. In fact, otherwise would have indicated a serious methodological flaw of the study. Staff in stores with no vision cannot use vision to guide their daily operations. The importance of vision in the literature is once again supported. In particular, researchers (e.g. Avery, 2005; Hamel \& Prahalad, 1989) who have asserted that an organization with a well-articulated vision can achieve sustained competitive advantage over those organizations lacking such a vision are endorsed. Humphreys (2004) who stated that, time and time again, if a corporate leader is successful, his or her vision is cited as the cause and lauded as the foundation of the leader's greatness is also supported.

However, the present study only asked store managers to indicate if they had a vision. Quality of store manager visions was not taken into account here (i.e. a bad vision is not going to bring about desirable leadership outcomes). Therefore, future research might want to take into account vision quality as a variable, because Senge (1990) argues that two types of vision exist: positive and negative visions. According to Senge, a positive vision emphasizes change and aspirations for growth, while a negative vision emphasizes continuing the status quo, even under changing environments. Moreover, Rafferty and Griffin (2004), drawing upon their study of a large Australian public sector organization, suggest that visions do not always create a positive impact on follower attitudes, and that one should distinguish between "strong" and "weak" visions as well as vision content to see their effectiveness. Future research might want to consider adopting a vision theory by Kantabutra (2009) which proposes that seven vision attributes of brevity, clarity, abstractness, stability, desirability, future orientation, desirability or ability to inspire enhance vision effectiveness initially through follower satisfaction.

Store managers with higher levels of passion tend to engage in behaviors that motivate staff, such as role modelling, rewarding, and encouraging, and bring about improvement in staff satisfaction in Australian retail stores. The view (Kantabutra, 2009; Nanus, 1992) that visionary leaders are said to live their vision by making all their actions and behaviors consistent with it, by creating a sense of urgency and passion for its attainment, and by expressing passion for their agendas in the hope of exciting others to support their vision is supported. Consistent with the finding is the view that outstanding leaders behave consistently with their vision (Bennis, 1984; Conger \& Kanungo, 1988; Kantabutra, 2009), because consistent behavior reflects leadership's integrity (e.g. Kantabutra, 2009; Kouzes \& Posner, 1987; Locke et al., 1991), which in turn affects follower satisfaction because followers 
recognize very soon to what extent their leader really stands behind the vision, not only within his/her mind, but also with his/her heart (Parikh \& Neubauer, 1993).

Store manager passion also directly predicts more frequent use of vision as a guide among staff in Australian retail stores. The notion (Kouzes \& Posner, 1995) that visionary leaders inspire a shared vision by their passionate belief that they can make a difference is underlined. Through their strong appeal and quiet persuasion, visionary leaders enlist followers in the dream, breathe life into the shared vision, and get people to see the exciting future possibilities and work towards them. It can be interpreted further that, in Australian retail stores, store managers might have enlisted their staff to work toward the vision by expressing their passionate belief. As a result, staff members more frequently use vision as a guide in their daily activities. In Australian retail stores, store managers may have expressed passion for their agendas for the stores in the hope of exciting staff to support their vision. They might have galvanized their vision-guided staff to action by infusing leadership with their own passion for work, thus tapping staff emotions as well as their minds. This suggests areas for future research.

Additionally, how Australian retail stores become passionate about their visions is still largely unknown. Common senses suggest that sources of vision may have some complex relationships with leader passion. Among a very few researchers, Mumford and Strange (2005) found that vision formation requires descriptive models, reflection, and abstraction of key goals and/or key causes. They also concluded that visioning involves a prescriptive model constructed through reflection and abstraction, and that visioning and planning should be treated as distinct constructs. Clearly, the relationship between the process in which vision is formed and the leader passion needs to be examined by future research.

Motivating behavior among store managers also indirectly predicts more frequent use of vision as a guide among staff in Australian retail stores, which directly predicts improvement in customer satisfaction. Supported is the view (Kantabutra \& Vimolratana, 2009; House \& Shamir, 1993) who claimed that visionary leaders impact follower attitudes, satisfaction, and performance. Visionary leaders motivate followers by instilling faith in a better future, particularly with goals that are distant, non-specific, and desired, and by creating internalized personal or moral commitment to the vision, mission, or goal. This predisposes an individual to want to continue the relationship, role, or course of action within his/her organization. Consistently, motivated staff members in Australian retail stores used their store manager visions to guide their own tasks. They have personal commitment to their store manager visions.

One way store managers did to motivate staff in the present study was to reward staff members who acted consistently with their visions, which naturally encouraged staff to use their visions to guide their daily operations. Numerous writers who suggest that visionary leaders motivate followers to achieve desirable performance (e.g. Awamleh \& Gardner, 1999; Bass, 1985; Kantabutra, 2009) have gained broad support here.

Motivation of staff directly predicts enhanced staff satisfaction. Locke et al.'s (1991) view that while achieving a challenging vision, leaders must encourage their followers to carry on when followers become exhausted, frustrated, and disenchanted is supported. Consistent with this finding is also the notion that effective leaders motivate their followers through devices such as the use of formal authority, role modelling, building selfconfidence, creating challenge through goal-setting, delegating, and rewarding and punishing (Locke et al., 1991).

Staff's use of vision as a guide directly predicts enhanced staff satisfaction in Australian retail stores. Davis and Meyer (1998) who stated that vision is regarded as possessing potent orienting capacities for followers who, without it, would have been lost are supported. Also supported is Kantabutra's vision theory (2009) which asserts that an effective vision be inclusive to all organizational interests, thereby allowing followers to interpret the vision in their own innovative ways to guide their duties. This individual creative interpretation, in turn, enhances follower satisfaction. Staff in Australian retail stores may have improved their own satisfaction by using their store managers' visions to guide their operations, pending future research.

In terms of practice, future research might also want to explore vision characteristics that would enable followers to use the vision more effectively. One relevant characteristic Kantabutra (2009) proposes is that an effective vision must be abstract or must not be a one-time, specific goal that can be met and then discarded, in order 
to allow followers throughout the entire organization to use it in their own interpretative ways. Findings from future research will help practitioners to develop effective vision for their own organizational use.

The literature on vision-based leadership primarily emphasizes the role of a leader in making organizations successful. The role of followers has not been emphasized, possibly because the unity focusing around one single leader has long been assumed. This traditional concept is being challenged by the significant staff vision guiding in the present study, which demonstrates the critical role that followers play in enhancing organizational performance via customer and staff satisfaction. These findings also echo a New Science view that effective leadership requires an alignment between leader and followers (Avery, 2004; Drath, 2001).

Moreover, supported by the critical role of followers in using vision as a guide and challenging the traditional single leader concept is the organic organization in which many organizational activities bypass the central leader, making the concept of the single central leader largely irrelevant (Avery, 2004). This new form of organization focuses on the importance of self-managing, self-leading followers where, among them, leadership can change depending on the most appropriate member at the time, rather than being formalized in one permanent leader (Warnecke, 1993). Decisions are made on mutual sense making basis. It is argued that tomorrow's organizations are likely to have many leaders, because multiple leaders, sharing the same vision, will be valuable as people cope with heterogeneous and dynamic environments, and the knowledge and issues become too complicated for one leader to effectively cope with (Avery, 2004). In this context, leadership will need to operate more through vision and values permeating the culture (Avery, 2004), which will become or replace the guiding vision (Drath, 1998). The significant staff vision guiding in the present study indeed indicates the increasing role that followers play in possibly enhancing organizational ability to deal with change.

Lastly, staff satisfaction does not directly predict customer satisfaction in the present study. However, it indirectly predicts enhanced customer satisfaction. A view that employee satisfaction leads to satisfied customers (e.g. Atchison, 1999; Faye \& Diane, 1995), has gained support from this finding. Clearly, customer satisfaction or dissatisfaction develops when a customer comes in contact with a staff member of a store.

\section{MANAGERIAL IMPLICATIONS}

To improve customer and staff satisfaction, Australian store managers should espouse vision. They should express their passionate beliefs in their vision by supporting to their vision by actions and acting consistently with their vision. They should also engage in behaviors that motivate staff. More specifically, they should act as a role model for staff, build staff's self confidence, reward staff who act consistently with vision, provide resources and support services to staff, and encourage staff to make more decisions regarding daily store operations. Staff should also be emotionally committed to store manager vision, and use the vision to guide daily store activities.

\section{CONCLUSIONS}

Stores with vision are associated with higher staff satisfaction and more vision guiding. Store manager passion directly predicts improvements in motivation of staff, vision guiding and staff satisfaction. Vision guiding directly predicts both improved staff and customer satisfaction. Staff satisfaction indirectly predicts improved customer satisfaction. Future research directions and managerial implications have been discussed.

\section{AUTHOR INFORMATION}

Sooksan Kantabutra is Chief Researcher of Leadership Research Group, College of Management, Mahidol University, Bangkok. Professor Kantabutra received his doctoral training in leadership from Macquarie Graduate School of Management in Sydney. He is a former management consultant with a leading global consulting firm where he advised multinational corporations on leadership and change.

Pisanu Vimolratana is a PhD candidate with the Leadership Research Group, College of Management, Mahidol University. Vimolratana's research interests include global leadership and corporate sustainability. 


\section{REFERENCES}

1. ANZ Industry Outlook (2009). ANZ Industry Outlook 2009. Melbourne, Australia: ANZ Economics \& Markets Research.

2. Atchison, T. (1999). The myths of employee satisfaction, Healthcare Executive, March/April, 19-23.

3. Australian Centre for Retail Studies (2006). Australian retail snapshot: ACRS secondary research report 2006, Caulfield East, Victoria: Faculty of Business and Economics, Monash University.

4. $\quad$ Avery, G. C. (2004). Understanding Leadership. London: Sage.

5. Avery, G. C. (2005). Leadership for Sustainable Futures. Cheltenham: Edward Elgar.

6. Awamleh, R., \& Gardner, W. (1999). Perceptions of leader charisma and effectiveness: the effects of vision content, delivery, and organizational performance. Leadership Quarterly, 10(3), 345-373.

7. Baetz, M. C., \& Bart, C. K. (1996). Developing mission statements which work. Long Range Planning, 29(4), 526-533.

8. $\quad$ Bass, B. M. (1985). Leadership and Performance Beyond Expectations. New York: Free Press.

9. Bass, B. M. \& Riggio, R. E. (2010). The Transformational Model of Leadership. In Hickman, G.R. (Ed.), Leading Organizations: Perspectives for a New Era (pp76-86), Thousand Oaks, California: Sage.

10. Baum, I. R., Locke, E. A., \& Kirkpatrick, S. A. (1998). A longitudinal study of the relation of vision and vision communication to venture growth in entrepreneurial firms. Journal of Applied Psychology, 83, 4354 .

11. Bennis, W. G. (1984). The four competencies of leadership, Training \& Development Journal, 28(8), 1419.

12. Chaleff, I. (1995). The Courageous Follower: Standing Up To and For Our Leaders. San Francisco: Berrett-Koehler.

13. Chia, Y. M. (1998). Motivation and junior supervisors' performance: The moderating role of work-group cohesion. International Journal of Management, 15(4), 441-453.

14. Collins, J. C., \& Porras, J. I. (1994). Built to Last: Successful Habits of Visionary Companies. London: Century.

15. Conger, J. A., \& Kanungo, R. N. (1988). Charismatic Leadership: The Elusive Factor in Organizational Effectiveness. San Francisco, CA: Jossey-Bass.

16. Daft, R. L. (1999). Leadership: Theory and Practice. Orlando: Dryden Press.

17. Daft, R. L. (2005). The Leadership Experience. Ohio: Thomson.

18. Davis, S., \& Meyer, C. (1998). Blur: The Speed of Change in the Connected Economy. San Francisco: Addison-Wesley.

19. Drath, W. H. (1998). Approaching the Future of Leadership Development, Greensboro, NC: Center for Creative Leadership.

20. Drath, W. H. (2001). The Deep Blue Sea: Rethinking the Source of Leadership. San Francisco, CA: JosseyBass.

21. Faye, M. \& Dianne, R. L. (1995). Transformational leadership and job satisfaction, Nursing Management, 26, 64JJ-64NN.

22. Ghoshal, S., \& Bruch, H. (2002). Managing organizational emotions, in Corporate Dossier. The Economic Times, New Delhi Edition, 25 October, 1.

23. Goleman, D. (1998). What makes a leader?. Harvard Business Review, 76(6), 92-102.

24. Hackl, P., Scharitzer, D., \& Zuba, R. (2000). Customer satisfaction in the Austrian food retail market. Total Quality Management, 11, S999-S1006.

25. Hair, J. F., Black, W. C., Babin, J. B., Anderson, R. E., \& Tatham, R. L. (2006). Multivariate Data Analysis. New Jersey: Pearson Prentice Hall.

26. Hamel, G., \& Prahalad, C. K. (1989). Strategic intent. Harvard Business Review, 89(3), 63-76.

27. Handy, C. (2002). What is a business for?. Harvard Business Review, 80(12), 48-55.

28. Heskett, J. L., Jones, T. O., Loveman, G. W., Sasser, W. E., \& Schlesinger, L. A. (1994). Putting the service-profit chain to work. Harvard Business Review, 72(2), 164-175.

29. House, R. J., \& Shamir, B. (1993). Towards the integration of transformational, charismatic and visionary theories. In M. M. Chemmers and R. Ayman (Eds.), Leadership theory and research (pp81-107), San Diego, CA: Academic Press. 
30. Humphreys, J. (2004). The vision thing. MIT Sloan Management Review, 45(4), 96.

31. Iaffaldano, M. T., \& Muchinsky, P. M. (1985). Job satisfaction and job performance: A meta-analysis. Psychological Bulletin, 97(2), 251-273.

32. Jick, T. D. (2001). Vision is 10\%, implementation the rest. Business Strategy Review, 12(4), 36-38.

33. Kantabutra, S. (2008). Vision effects in Thai retail stores: practical implications. International Journal of Retail \& Distribution Management, 36(4), 323-342.

34. Kantabutra, S. (2009). Toward a behavioral theory of vision in organizational settings. Leadership and Organization Development Journal, 30(4), 319-337.

35. Kantabutra, S. (2010). What do we know about vision?. In G. R. Hickman (Ed.), Leading Organizations: Perspectives for a New Era, Thousand Oaks, California: Sage.

36. Kantabutra, S., \& Avery, G. C. (2002). Proposed model for investigating relationships between vision components and business unit performance. Journal of the Australian and New Zealand Academy of Management, 8(2), 22-39.

37. Kantabutra, S. \& Avery, G. C. (2010). The power of vision: Statements that resonate. Journal of Business Strategy, 31(1), 37-45.

38. Kantabutra, S. \& Vimolratana, P. (2009). Vision-based leadership: Relationships and consequences in Thai and Australian retail stores. Asia-Pacific Journal of Business Administration, 1(2), 165-188.

39. Kotter, J. P. (1990). A Force for Change: How Leadership Differs from Management. New York: Free Press.

40. Kotter, J. P. (1996). Leading Change. Boston, MA: Harvard Business School Press.

41. Kouzes, J. M., \& Posner, B. Z. (1987). The Leadership Challenge: How to Get Extraordinary Things Done in Organizations. San Francisco: Jossey-Bass.

42. Kouzes, J. M., \& Posner, B. Z. (1995). The Leadership Challenge (2 ${ }^{\text {nd }}$ ed.). San Francisco: Jossey-Bass.

43. Lipton, M. (1996). Demystifying the development of an organizational vision. Sloan Management Review, 37(4), 83-91.

44. Locke, E. A. (1976). The nature and causes of job satisfaction. In M. D. Dunnette (Ed.), Handbook of industrial and organizational psychology (pp1297-1349), Chicago, IL: Rand McNally.

45. Locke, E. A., Kirkpatrick, S., Wheeler, J. K., Schneider, J., Niles, K., Goldstein, H., Welsh, K., \& Chah, D. O. (1991). The Essence of Leadership. New York: Lexington Books.

46. Mumford, M. D., \& Strange, J. M. (2005). The origins of vision: Effects of reflection, models, and analysis. Leadership Quarterly, 16, 121-148.

47. Nanus, B. (1992). Visionary Leadership: Creating a Compelling Sense of Direction for Your Organization. San Francisco: Jossey-Bass.

48. Nunnally, J. L. (1978). Psychometric Theory. New York: McGraw-Hill.

49. Oliver, J. (1998). Invest in people and improve profitability and productivity. Management Today, March, $90-91$.

50. Panda, A., \& Gupta, R. K. (2003). Why mission statements become a show piece? Case of an Indo-American joint venture. VIKALPA, 28(2), 23-47.

51. Parikh, J., \& Neubauer, F. (1993). Corporate visioning. In D. E. Hussey (Ed.), International Review of Strategic Management 4 (pp 105-116), Chichester: Wiley.

52. Passikoff, R. (1997). The limits of customer satisfaction. Brandweek, 38(9), 17.

53. Rafferty, A. E., \& Griffin, M. G. (2004). Dimensions of transformational leadership: Conceptual and empirical extensions. Leadership Quarterly, 15, 329-354.

54. Robbins, S. R., \& Duncan, R. B. (1988). The role of the CEO and top management in the creation and implementation of strategic vision. In D. C. Hambrick (Ed.), The executive effect: concepts and methods for studying top managers (pp137-162), Greenwich, CT: JAI Press.

55. Rynes, S. L., Colbert, A. E., \& Brown, K. G. (2002). HR professionals' beliefs about effective human resource practices: Correspondence between research and practice. Human Resource Management, 41, 149.

56. Sashkin, M. (1988). The visionary leader. In J. A. Conger \& R. N. Kanungo (Eds.), Charismatic leadership: The elusive factor in organizational effectiveness (pp122-160), San Francisco: Jossey-Bass.

57. Senge, P. M. (1990). The Fifth Discipline: The Art \& Practice of the Learning Organization. New York: Currency Doubleday.

58. Slavitt, D., Stamps, P., Piedmont, E., \& Hasse, A. (1986). Index of Work Satisfaction. MI: University of Michigan Press.

59. Vroom, V. H. (1964). Work and motivation. New York: Wiley.

60. Warnecke, H. J. (1993). The Fractal Company: A Revolution in Corporate Culture. Berlin: Springer-Verlag.

61. Yukl, G. A. (1998). Leadership in Organizations (4 ${ }^{\text {th }}$ ed.), New Jersey: Prentice Hall. 